\title{
A rare cause of acute abdomen: Spontaneous intraperitoneal hydatid cyst rupture
}

\author{
Nadir bir akut batın nedeni: Spontan intraperitoneal kist hidatik ruptürü
}

\author{
Murat Özban, Onur Birsen, Halil Erbiş, Sinan Sayır, Göksel Sarohan, Tufan Ersöz, Çağatay Aydın, \\ Burhan Kabay
}

Pamukkale Üniversitesi Tıp Fakültesi Genel Cerrahi AD, Denizli

\begin{abstract}
Human hydatid disease usually occurs by infestation with Echinococcus granulosus or rarely with Echinococcus multilocularis. Hydatid cyst occurs endemically in the Mediterranean region including Turkey. It's still an important public health problem in Turkey. We present a case report of an 84-year-old female patient who presented to the emergency department beause of the nausea- vomitting, abdomial pain and a decreased level of consciousness. Her physical examination findings were as follows: pulse 112/ dk, blood pressure $84 / 47 \mathrm{~mm}$ $\mathrm{Hg}$, body temperature $38,1^{\circ} \mathrm{C}$. Abdominal tomography showed a ruptured hydatid cyst and intraperitoneal fluid. Rupture of a hydatid cyst into the abdominal cavity is a rare complication of the hydatid disease and leads to a full blown anaphylactic reaction and severe, life-threatening complications. The relationship between the cysts with the blood vessels and the bile ducts; and the conditions, in which the patient presented at the emergency department, are other parameters affecting the surgery outcome and type. However, a high rate of morbidity and mortality is usually encountered in ruptured cyst hydatid cases.
\end{abstract}

Pam Med J 2015;8(1):59-61

Key words: Cyst hydatid, rupture, intraperitoneal.

\section{Özet}

Kist hidatik hastalığı genellikle Ekinokokus granülosis infestasyonu veya nadiren Ekinokokus multilokülaris aracılığı ile özellikle Türkiye dahil Akdeniz bölgesinde endemik olabilen bir rahatsızlıktır. Ülkemizde halen önemli bir halk sağlığı sorunudur. Vaka sunumumuzda acil servise başvuran 84 yaşında bir bayan hastayı tartıştık. Başvuru şikayeti bulantı, kusma ve karın ağrısı olan hastanın beraberinde bilinç bulanıklığı da gelişti. Fizik incelemesinde nabız 112/dk, kan basıncı $84 / 47$ mmHg ve vücut ısısı 38.1 derece idi. Çekilen batın tomografisinde ruptüre kist hidatik ve batında yaygın serbest sıvı saptandı Ruptüre kist hidatik, abdominal kavitede nadir görülen anaflaksiye yol açarak ölümcül seyredebilen bir komplikasyondur. Kistin kan damarları ve safra kanalları ile ilişkisi, hastanın acil servise geldiği zaman ki durumu, operasyon sürecini etkileyen faktörlerdir. Bununla birlikte, genellikle yüksek morbidite ve mortalite oranlarına sahiptir.

Pam Tıp Derg 2015;8(1):59-61

Anahtar sözcükler: Kist hidatik, ruptür, intraperitoneal.

\section{Introduction}

Human hydatid disease usually occurs by infestation with Echinococcus granulosus and less frequently with Echinococcus multilocularis [1]. Hydatid cyst occurs endemically in the Middle and Far East, South America, Africa, Australia, New Zealand and in the Mediterranean region including Turkey. It is still an important public health problem in Turkey. The organs commonly affected by hydatid cyst are respectively the liver and the lungs. Most of the patients are diagnosed incidentally or are asymptomatic until complications occur. Its diagnosis is generally made by ultrasonography and computerized tomography. Complications of hepatic hydatid cysts are rupture and secondary bacterial infection [2]. Perforation of the cyst may occur traumatically or spontaneously because of the increased intracystic pressure. It is a rare but

Murat Özban

Yazışma Adresi: Pamukkale Üniversitesi Tıp Fakültesi Genel Cerrahi AD, Denizli

e-mail: muratozban@yahoo.com

Gönderilme tarihi: 21.07.2014

Kabul tarihi: 22.10 .2014 
life threatening complication of spontaneous intraperitoneal rupture of the cyst. It is possible to be confronted with acute abdominal semptoms such as tenderness, defence, and rebound in the emergency department. Therefore, it is necessary to review the other acute abdomen symptoms with a differential diagnosis, as well. Rupture of a hydatid cyst requires emergency surgical intervention [3]. In this study, we aimed to draw attention to a case which we came across with acute abdomen in the emergency department that could have been diagnosed differently.

\section{Presentation}

An 84 year-old female patient presented to the emergency department because of the nausea, vomiting, abdominal pain and a decreased level of consciousness. Her physical examination findings were pulse $112 / \mathrm{dk}$, blood pressure $84 / 47 \mathrm{~mm} \mathrm{Hg}$, body temperature 38,1 ${ }^{\circ} \mathrm{C}$. The information obtained from her history was that she had a surgery because of a hydatid cyst 6 years ago. When the laboratory findings were evaluated, her white blood cell count was $28000 / \mathrm{mm}^{3}$. Her abdominal tomography showed a cystic-solid mass in the left liver lobe that was an average $6 \mathrm{~cm}$ in size and lamellar in structure (Figure 1). From its appearance, it was interpreted as ruptured hydatid cyst, at first. In addition, there was intra-abdominal free fluid too (Figure 2). The patient was pre-diagnosed with a high risk of a potential perforation and was operated on immediately. The informed consent was obtained from the patient before the surgery. During the surgery,a ruptured hydatid cyst lying exophytically in left liver inferior lobe was determined. Intra abdominal free fluid was also observed. After the abdomen had been washed with hypertonic saline, vesicles were removed from the cyst wall by capitonnage. The abdomen was washed again and drains were placed and the surgery completed. The patient deteriorated after she was taken into the intensive care unit, where she went into cardiopulmonary arrest and was accepted as an exitus because she did not want resuscitation.

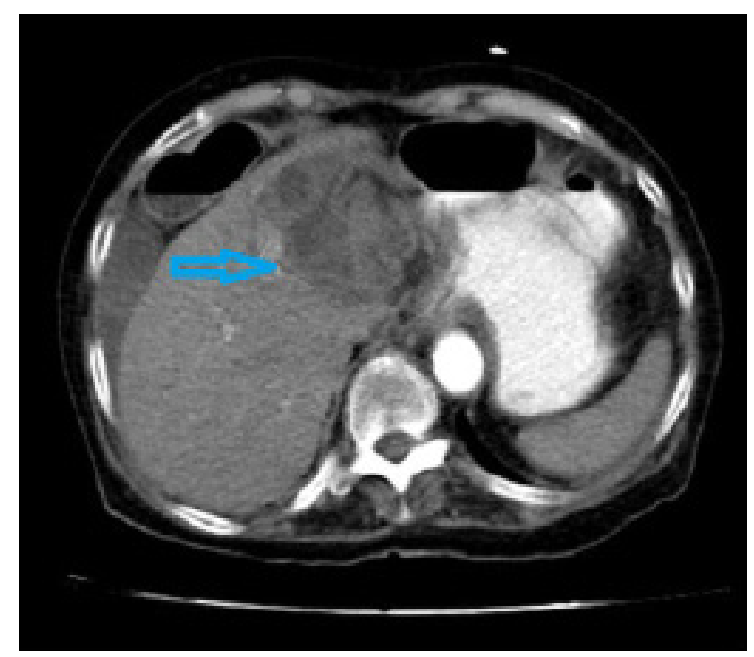

Figure 1. Cystic- solid mass in left liver lobe that was lamellar structure and average $6 \mathrm{~cm}$ size.



Figure 2. Ruptured hydatid cyst and intraabdominal free fluid.

\section{Discussion}

Rupture of a hydatid cyst into the abdominal cavity is a rare complication of the hydatid disease and causes serious problems and severe, life-threatening complications, including anaphylaxis. However, healed cases without anaphylaxis have been reported in the literature as fatal cases with rupture of the cyst into the peritoneum [3-5]. Rupture can occur spontaneously or following a trauma. The risk of rupture is reported to increase with the increased size of the cyst and intracystic pressure [6]. Complications occur in 5 to $40 \%$ patients with hepatic hydatid cysts and include the formation of small cystobiliary fistulas, cyst rupture into the biliary tree, biliary compression, cyst infection, hydatid allergy, membranous glomerulitis, and 
intraperitoneal rupture [7]. The main risk factors predisposing to rupture include young age, cyst diameter of $10 \mathrm{~cm}$, and superficial cyst location. Young age is a risk factor because of the greater frequency of traumatic events and higher prevalence of hydatid disease in children and adolescents than in adults. Increased cyst diameter, which increases the internal tension, and superficial location of the cyst are important risk factors for rupture, even with minor trauma. The incidence of lifethreatening anaphylactic shock is $1.4 \%$. These findings suggest that allergic reactions may be infrequent, but it may be prudent to maintain awareness of the potential for developing anaphylaxis. Therefore, immediate medical treatment for allergic reactions is advised [8]. In this case, immediately surgery must be planned and post-operative medical treatment must be continued. Partial pericystectomy and drainage are the most frequent surgical procedures. Most important criteria identifying the medical or the conservative approach are the number, the size, and the localization of the cysts. The relation of the cysts between the blood vessels and the bile duct; and the conditions in which the patient presented in the emergency department are other parameters affecting the surgery outcome and type.

In conclusion, spontaneous rupture of cyst hydatid is a rare but a fatal clinical picture which must be taken into account in the differential diagnosis of acute abdomen in the emergency departments especially in endemic areas. However, a high rate of morbidity and mortality is generally encountered in ruptured cyst hydatid surgery cases.

There was no potential conflict of interest relevant to the article among the authors and no financial support was reported.

Conflict of interest: The authors declared no conflict of interest.

\section{References}

1. Mouaqit $\mathrm{O}$, Hibatallah A, Oussaden A, Maazaz K, Taleb KA. Acute intraperitoneal rupture of hydatid cysts: a surgical experience with 14 cases. World J Emerg Surg. 2013;Jul 26;8:28.

2. Barnes SA, Lillemoe KD: Liver abscess and hydatid cyst disease. In Maingot's abdominal operations. 10th edition. Edited by Zinner MJ, Schwartz SI, Ellis $\mathrm{H}$. Appleton \& Lange: Stamford, CT; 1997;1513-45.

3. Beyrouti MI, Beyrouti R, Abbes I, et al: Acute rupture of hydatid cysts in the peritoneum: 17 cases. Presse Med 2004;33:378-384
4. Di Cataldo A, Lanteri R, Caniglia S, et al: A rare complication of the hepatic hydatid cyst: intraperitoneal perforation without anaphylaxis. Int Surg 2005;90:424.

5. Kurt N, Oncel M, Gulmez S, Ozkan Z, Uzun H: Spontaneous and traumatic intraperitoneal perforations of hepatic hydatid cysts: a case series. J Gastrointest Surg 2003;7:635-41.

6. Yuksel M, Kir A, Ercan S, Batirel HF, Baysungur V: Correlation between sizes and intracystic pressures of hydatid cysts. Eur J Cardiothorac Surg 1997;12:9036.=

7. Feleppa C, D’Ambra L, Berti S, Magistrelli P, Sani C, Falco E. Laparoscopic treatment of traumatic rupture of hydatid hepatic cyst-is it feasible?: a case report. Surg Laparosc Endosc Percutan Tech 2009;19:140142.

8. Akcan A, Akyildiz H, Artis T, Ozturk A, Deneme MA, Ok $E$ et al. Peritoneal perforation of liver hydatid cysts: clinical presentation, predisposing factors, and surgical outcome. World J Surg 2007;31:1284-1291. 